\title{
Kenaikan Tingkat Kebisingan Ruangan Kelas Akibat Pengaruh Penyejuk Udara dan Lalu Lintas
}

\author{
I Made Indradjaja M. Brunner ${ }^{1}$, Susy F. Rostiyanti ${ }^{2}$ \\ ${ }^{1}$ Electrical Engineering Master Program, STT PLN, Jakarta \\ ${ }^{2}$ Construction Engineering and Management, Universitas Agung Podomoro, Jakarta \\ *Koresponden email: imade.brunner@sttpln.ac.id
}

Diterima: 15 Desember 2019

Disetujui: 18 Desember 2019

\begin{abstract}
Noise level in the classroom is a factor affecting the learning process. This study aims to determine the level of indoor noise of a private university campus in West Jakarta. Measurements were made using Sound Level Meter that can record the noise level every second with accuracy up to $0.1 \mathrm{dBA}$. Sampling was carried out in a number of classrooms in an empty condition, closed door, and air conditioning system either in off or on position. Classrooms are distinguished based on the condition of the wall, namely the window facing the outside environment and massive walls without windows to the environment. The measurement results indicate a significant difference in noise level at a $95 \%$ confidence level in an empty classroom when the air conditioning system is not functioning and when the system is running. Differences also occur in classrooms with and without windows to the environment. The difference shows that the classroom in an empty condition can experience an increase in latent noise level due to the operation of the air conditioner between 5.78-16.49 dBA. Increased noise from the environment including the highway is about $3 \mathrm{dBA}$ for classrooms located on the $5^{\text {th }}$ floor, with a horizontal distance about 100 meters from the highway and has thick and permanent glass windows.
\end{abstract}

Keywords: indoor noise, classroom, air conditioner, traffic, sound level meter

\begin{abstract}
Abstrak
Tingkat kebisingan dalam ruangan kelas merupakan salah satu faktor yang dapat mempengaruhi proses belajar mengajar. Penelitian ini bertujuan untuk mengetahui tingkat kebisingan dalam ruangan di kampus universitas swasta di Jakarta Barat. Pengukuran dilakukan dengan menggunakan alat Sound Level Meter yang dapat mencatat tingkat kebisingan setiap detik sekali dengan keakuratan hingga 0,1 dBA. Sampling dilakukan pada beberapa ruangan kelas dalam keadaan kosong, pintu tertutup, serta sistem penyejuk udara dalam keadaan mati dan nyala. Ruangan kelas dibedakan berdasarkan kondisi dinding yaitu dengan jendela yang menghadap ke lingkungan luar serta berdinding masif tanpa jendela ke lingkungan. Hasil pengukuran menunjukkan adanya perbedaan tingkat kebisingan yang signifikan pada tingkat kepercayaan 95\% pada ruangan kelas kosong saat sistem penyejuk udara tidak berfungsi dan saat sistem berfungsi. Perbedaan juga terjadi pada ruangan kelas yang memiliki dan tanpa jendela ke lingkungan. Perbedaan tersebut menunjukkan bahwa ruangan kelas dalam keadaan kosong dapat mengalami peningkatan kebisingan yang bersifat laten akibat pengoperasian alat penyejuk udara antara 5,78-16,49 dBA. Peningkatan kebisingan dari lingkungan termasuk jalan raya adalah sekitar 3 dBA untuk ruangan kelas yang berada pada lantai 5, berjarak horisontal sekitar 100 meter dari jalan raya dan memiliki jendela kaca tebal dan permanen.
\end{abstract}

Kata Kunci: kebisingan ruangan, ruang belajar, penyejuk udara, lalu lintas, sound level meter

\section{Pendahuluan}

Suara dihasilkan melalui gelombang yang memberikan getaran dalam medium gas, cair, atau padat yang kemudian diterima indra pendengaran dan diterjemahkan menjadi suatu pesan tertentu [1], [2]. Kebisingan pada dasarnya adalah bentuk lain dari suara. Meskipun secara fisik, keduanya sama, kebisingan dianggap sebagai bentuk suara yang tidak diinginkan dan gangguan pada pita frekuensi yang bermanfaat (useful frequency band) [3].

Kelas sebagai tempat untuk proses belajar mengajar harus memenuhi beberapa persyaratan untuk menjaga kinerja proses. Salah satu kendala dalam menjaga kinerja proses belajar mengajar adalah kebisingan. Kebisingan tidak hanya mempengaruhi kinerja siswa dalam menerima informasi tetapi juga memberikan dampak negatif bagi guru atau dosen. Kebisingan berdampak negatif pada siswa dalam mempertahankan perhatian visual; menerima informasi dari dosen karena gangguan dalam 
memersepsikan suara; menghafal tugas yang membutuhkan pemrosesan tinggi; dan lulus ujian standar nasional [4], [5]. Di sisi lain, dampak negatif dari kebisingan terhadap dosen adalah kelelahan, stres, dan penyakit di kepala dan tenggorokan [6].

Kepedulian tentang efek kebisingan terhadap proses belajar mengajar telah menginisiasi beberapa negara untuk menetapkan ambang batas tingkat kebisingan. American National Standard Institute mengembangkan standar ANSI S12.60-2002, Acoustical Performance Criteria, Design Requirements and Guidelines for Schools yang merekomendasikan standar kebisingan maksimum pada $35 \mathrm{dBA}$ di ruang kelas yang tidak dihuni (unoccupied classroom) untuk mengurangi gangguan kebisingan di ruang kelas [7]. Negara-negara lain juga menetapkan standar yang bervariasi antara 30 hingga $50 \mathrm{dBA}$ untuk kelas tertutup dan terbuka yang tidak dihuni [8]. Penelitian ini menyimpulkan bahwa ruang kelas kosong dianggap baik ("Good") jika tingkat kebisingannya adalah $<30 \mathrm{~dB}(\mathrm{~A})$ dan dianggap buruk ("Bad") jika memiliki tingkat kebisingan $>40 \mathrm{~dB}(\mathrm{~A})$.

Sementara itu, Indonesia tidak memiliki standar mengenai tingkat kebisingan maksimum di kelas. Regulasi yang digunakan saat ini di Indonesia adalah Keputusan Menteri Negara Lingkungan Hidup nomor Kep-48/MENLH/11/1996 tentang Ambang Batas Tingkat Kebisingan. Namun regulasi ini hanya mengatur ambang batas tingkat kebisingan untuk lingkungan sekolah secara umum. Keputusan tersebut merekomendasikan bahwa tingkat kebisingan untuk lingkungan sekolah dari suara luar adalah $55 \mathrm{dBA}$ [9].

Istilah ruang kelas tidak dihuni atau kosong (unoccupied classroom) diterapkan pada kondisi ruang kosong tanpa manusia. Ambang batas kebisingan untuk kelas yang tidak dihuni memasukkan unsur kebisingan dari sistem ventilasi dan sumber eksternal dan mengecualikan kebisingan dari kegiatan pengajaran di dalam area sekolah [10], [11], [12]. Dengan demikian suara yang berasal dari peralatan yang digunakan untuk mengajar, suara yang bersumber dari aula dan ruang yang berdekatan lainnya yang menambahkan kebisingan tidak dapat dimasukkan dalam ambang yang ditentukan. Pengukuran tingkat kebisingan ruang kosong biasanya dilakukan untuk menjelaskan karakteristik dasar ruangan tanpa dipengaruhi oleh keberadaan penghuni [13]. Karakteristik meliputi geometri dan desain kamar; dan bahan-bahan yang memberikan efek serap [10].

Walaupun beberapa standar merekomendasikan tingkat kebisingan ruang kelas $35 \mathrm{dBA}$, ambang ini jarang dapat dipenuhi. Penelitian di Ohio, Amerika menemukan bahwa di antara 32 ruang kelas sekolah dasar yang tidak dihuni hanya 4 ruang kelas yang diperiksa memiliki tingkat kebisingan pada atau di bawah $35 \mathrm{dBA}$ [11]. Keempat ruang kelas tersebut merupakan ruang kelas yang lebih baru dengan desain yang disesuaikan memenuhi ambang batas. Hasil penelitian ini menunjukkan bahwa keberadaan sistem HVAC meningkatkan tingkat kebisingan sebanyak $15 \mathrm{dBA}$. Akibatnya ruang kelas yang menjadi subyek penelitian tidak dapat memenuhi standar ambang batas kebisingan. Penyelidikan tingkat kebisingan di 13 sekolah menengah di Inggris juga dilakukan [10]. Di antara sekolah-sekolah tersebut, hanya tiga sekolah yang memiliki ruang kelas tidak dihuni dengan tingkat kebisingan melebihi $35 \mathrm{dBA}$. Tingkat kebisingan tertinggi ada di sekolah di tengah kota. Di sekolah itu, kebisingan eksternal mencapai tingkat tertinggi di antara sekolah lainnya. Temuan lain dalam penelitian ini menunjukkan bahwa jumlah ruang kelas yang memenuhi rekomendasi ambang kebisingan meningkat secara signifikan setelah dikeluarkannya Building Bulletin 93 Acoustic Design of Schools.

Standar tingkat kebisingan di Inggris merekomendasikan tingkat kebisingan kurang dari 35 dBA di ruang kosong seperti yang dinyatakan dalam buletin. Untuk tingkat universitas, pengukuran kebisingan kelas yang tidak dihuni belum banyak dilakukan. Salah satu penelitian pada sebuah universitas menarik kesimpulan bahwa standar $35 \mathrm{dBA}$ di ruang kelas yang kosong dapat dicapai tetapi tingkat kebisingan meningkat secara signifikan ketika kebisingan akibat sistem ventilasi muncul [6]. Kebisingan pada kegiatan akademik yang disebabkan oleh kebisingan latar belakang (background noise) ditengarai dapat mempengaruhi persepsi ucapan dan pengenalan suara [14]. Kondisi ruang kelas sebagai sarana komunikasi verbal dengan tingkat kebisingan tinggi dapat memperburuk komunikasi sehingga menurunkan efisiensi proses belajar mengajar.

Penelitian mengenai tingkat kebisingan juga menunjukkan beberapa hasil lain. Siswa sekolah dasar di Kanada menunjukkan kinerja yang baik dalam kondisi ruang kelas dengan tingkat kebisingan kurang dari $35 \mathrm{dBA}$ [15]. Penelitian ini merekomendasikan bahwa tingkat kebisingan maksimum 35dBA menjadi komponen yang ideal untuk mencapai komunikasi yang hampir ideal bagi siswa. Penelitian terhadap akustik ruang kelas menyimpulkan bahwa akustik yang baik tergantung pada ketinggian ruangan dan bahan langit-langit. Semakin tinggi ketinggian ruang kelas membuat kejelasan bicara siswa lebih baik [10]. Penelitian ini juga menegaskan bahwa jumlah siswa di kelas dan usia mereka mempengaruhi tingkat kebisingan. 
Penelitian tingkat kebisingan dan dampaknya terhadap institusi pendidikan seperti perguruan tinggi di Indonesia belum banyak dilakukan. Salah satu penelitian menyimpulkan bahwa mengurangi tingkat kebisingan dapat dilakukan dengan pemilihan lokasi sekolah pada area dengan kepadatan penduduk yang rendah dan jauh dari sumber bising [16]. Sementara itu, penelitian lain menyimpulkan bahwa tingkat kebisingan dapat dikurangi dengan pemilihan material kedap suara yang mampu meningkatkan kualitas akustik ruangan [17]. Namun sejauh mana besaran pengaruh tingkat kebisingan yang ditimbulkan dari sumber suara eksternal dan sistem pendingin di area universitas belum banyak dikaji. Penelitian ini bertujuan untuk mengetahui seberapa besar pengaruh suara akibat sistem penyejuk udara dan suara eksternal yang masuk ke dalam ruangan melalui medium kaca terhadap tingkat kebisingan ruang belajar.

\section{Metodologi}

\subsection{Waktu dan Tempat}

Lokasi sampling dilakukan di dalam sebuah kampus universitas swasta di daerah Jakarta Barat. Kampus ini memiliki keunikan karena berada di dalam sebuah bangunan komersial dan berada pada lantai 5 dari bangunan tersebut. Sebagian besar ruangan tidak memiliki jendela yang menghadap ke lingkungan luar. Hanya ruangan dosen, perpustakaan, serta ruang kuliah R.503, R.505, R.506, R.507, R.510, dan R.512 yang memiliki jendela. Ruang dosen menghadap ke sisi dalam kawasan komersial atau arah Barat Daya, sedangkan ruangan lain yang berjendela menghadap ke arah jalan raya atau arah Timur Laut. Jendela yang ada di kampus ini merupakan jendela kaca yang tidak dapat dibuka. Sirkulasi udara di dalam areal kampus seluruhnya menggunakan sistem penyejuk udara atau Air Conditioning (AC).

Ruangan perpustakaan, dan ruang kuliah R.503, R.505, R.506, R.507 serta beberapa ruangan di sekitarnya menggunakan sistem AC terpusat yang tidak dapat diatur oleh pengguna. Sistem AC di ruangan lainnya, termasuk ruangan dosen, ruang kuliah R.510, R.512 dan lainnya menggunakan unit tersendiri dan dapat difungsikan oleh pengguna. Gambar 1 menunjukkan denah ruangan-ruangan di lingkungan kampus.

Jarak terdekat horizontal antara jendela luar ruang perpustakaan dengan jalan raya adalah sekitar 80 meter dan terjauh sekitar 130 meter. Kepadatan lalu lintas di salah satu ruas jalan terdekat dengan bangunan komersial tempat lokasi penelitian berada, telah mencapai lebih dari 20.000 kendaraan ringan dan 26.000 sepeda motor pada jam 06.00-09.00 WIB dan 14.00-17.00 WIB setiap hari kerja [18]. Kepadatan lalu lintas ini belum termasuk kendaraan yang melintas jalan tol dalam kota, yang berdasarkan data dari Kementerian PUPR dapat mencapai 117.861.778 kendaraan pada tahun 2017 atau sekitar 322.000 kendaraan per hari.

Kegiatan sampling dilakukan pada hari Minggu, yaitu pada saat kampus tutup dan tidak ada kegiatan. Hal ini dilakukan untuk mengetahui kondisi tenang yang terjadi di dalam lingkungan kampus. Pengambilan sampel tingkat kebisingan dilakukan di beberapa ruang kelas dan ruangan dosen. Ruangan kelas yang dipilih adalah yang memiliki sistem AC tersendiri, sehingga dapat dioperasikan sesuai kebutuhan. Tabel 1 berikut menunjukkan ruangan tempat pengambilan sampel tingkat kebisingan dilakukan.

\subsection{Peralatan Sampling}

Peralatan sampling untuk menentukan tingkat kebisingan menggunakan alat Sound Level Meter (SLM) sebanyak 4 buah. Dua alat SLM bermerek TenMars (TM-103) dengan nomor seri 120500053 dan 150101270. Dua alat lain adalah SLM merek Testo 816-1 dengan nomor seri 14302 dan 14039. Baterai pada seluruh alat SLM tersebut telah diganti dengan batu baterai yang baru dan sesuai dengan spesifikasi untuk masing-masing alat. Hal ini dilakukan untuk menjamin kontinuitas pengambilan dan perekaman data selama sampling berlangsung. Setelah sumber tenaga diganti maka alat SLM dikalibrasi dengan menggunakan alat kalibrator guna mendapatkan hasil pengukuran yang tepat. Setelah dikalibrasi, seluruh alat SLM dinyalakan dan didudukkan dalam posisi tegak dengan batang mikrofon diberikan gabus filter. Pembacaan dari ke-empat alat tersebut diamati guna memberikan hasil yang setara. Ternyata, hasil yang ditampilkan oleh seluruh alat setelah dilakukan kalibrasi menunjukkan pengukuran yang serupa sehingga dapat dipakai dalam pengambilan sampel. 




Gambar 1. Tata letak ruangan kampus dan titik pengambilan sampel Sumber: Hasil analisis (2018)

Tabel 1. Karakteristik lokasi pengambilan sampel kebisingan

\begin{tabular}{clll}
\hline Kode & \multicolumn{1}{c}{ Jenis Ruangan } & $\begin{array}{c}\text { Sistem } \\
\text { AC }\end{array}$ & \multicolumn{1}{c}{ Dinding Pembatas } \\
\hline ACC & Ruang Laboratorium & Tersendiri & $\begin{array}{l}\text { Memiliki dinding kaca menghadap ke dalam area } \\
\text { kampus }\end{array}$ \\
AUD & Ruang Auditorium & Tersendiri & $\begin{array}{l}\text { Dinding masif, tidak ada jendela } \\
\text { Memiliki dinding kaca menghadap ke arah kawasan }\end{array}$ \\
DOSEN & Ruangan Kerja Dosen & Tersendiri & $\begin{array}{l}\text { komersial } \\
\text { R. }\end{array}$ \\
R.510 & Studio Gambar Kecil & Tersendiri & Memiliki dinding kaca menghadap ke arah jalan raya \\
R.511 & Ruang Kuliah dan Theater & Tersendiri & Dinding masif, tidak ada jendela \\
R.512 & Ruang Laboratorium Fisika & Tersendiri & Memiliki dinding kaca menghadap ke arah jalan raya \\
R.513 & Ruang Kelas & Tersendiri & Dinding masif, tidak ada jendela \\
R.514 & Ruang Kelas & Tersendiri & Dinding masif, tidak ada jendela \\
R.515 & Ruang Kelas & Tersendiri & Dinding masif, tidak ada jendela \\
R.518 & Ruang Simulasi Sidang & Tersendiri & Dinding masif, tidak ada jendela \\
R.520 & Ruang Kelas & Tersendiri & Dinding masif, tidak ada jendela \\
R.521 & Ruang Kelas & Tersendiri & Dinding masif, tidak ada jendela \\
R.522 & Ruang Kelas & Tersendiri & Dinding masif, namun ada pintu menuju teras kawasan \\
Romersial
\end{tabular}

Sumber: Hasil analisis (2018)

Foto dari kedua jenis alat SLM yang digunakan pada kegiatan penelitian ini disajikan pada Gambar 2. Angka yang tertera pada gambar menunjukkan kondisi pada saat pelaksanaan sampling dan bukan pada saat disetarakan setelah kalibrasi.

Kedua jenis SLM yang digunakan memiliki kemampuan untuk mendeteksi tingkat kebisingan hingga perbedaan $0,1 \mathrm{dBA}$ (desibel skala A) dan merekam perubahan tingkat kebisingan setiap detik. Pembacaan data dari alat SLM dilakukan dengan menggunakan sebuah kabel khusus yang 
menghubungkan porta dari SLM ke porta USB di perangkat komputer. Pengontrolan kinerja dan data dari alat SLM dapat dilakukan setelah piranti lunak khusus dipasangkan di perangkat komputer. Pada penelitian ini, sebuah perangkat komputer yang telah dipasangi piranti lunak khusus dipakai sebagai pengatur kinerja SLM dalam melakukan pemantauan dan mengunduh data hasil pemantauan dari setiap alat SLM. Seluruh alat SLM diatur dengan kondisi: a) waktu pengambilan sampel setiap 1 detik sekali; b) pembobotan waktu diatur pada kondisi cepat (Fast) untuk memungkinkan antisipasi perubahan kebisingan hingga 125 milisekon; c) pengukuran kebisingan dilakukan dengan pembobotan A guna memperoleh hasil dalam skala dBA (desibel A); serta d) waktu dan tanggal disesuaikan dengan sistem waktu di komputer.

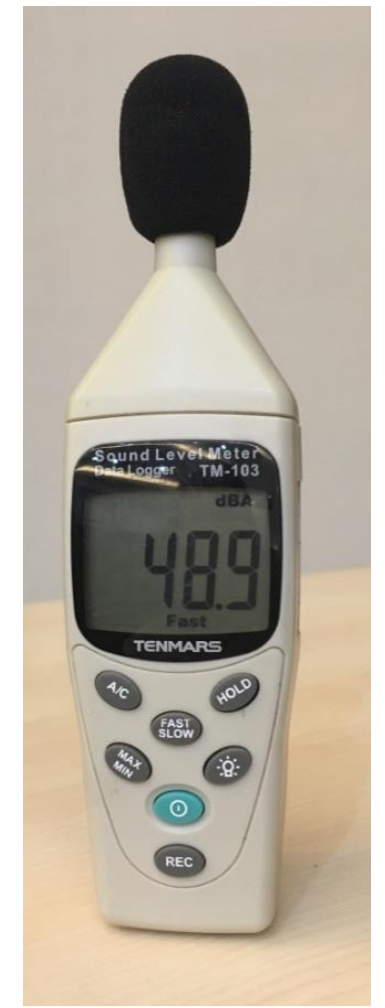

(a)

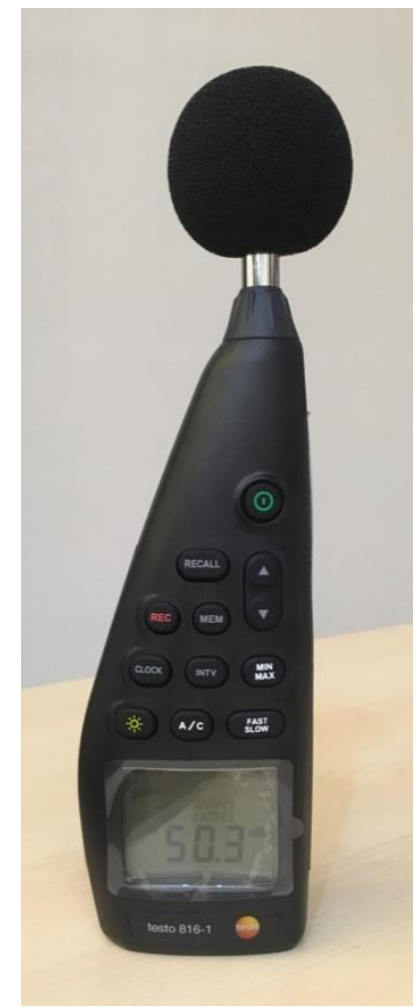

(b)

Gambar 2. Alat Sound Level Meter Jenis (a) TenMars TM-103, (b) Testo 816-1 Sumber: Foto pribadi penulis (2018)

\subsection{Pengambilan Sampel Tingkat Kebisingan}

Pengambilan data tingkat kebisingan di dalam ruangan dilakukan dengan dua perlakuan yang berbeda, yaitu kondisi "kosong tanpa AC" serta "kosong dengan AC." Kondisi "kosong tanpa AC" adalah saat ruangan kosong, pintu tertutup penuh, serta sistem AC tidak dioperasikan. Pengukuran dalam kondisi "kosong tanpa AC" dilakukan di 6 ruangan dengan kode: AUD, DOSEN, R.510, R.512, R.518, dan R.524. Pengukuran dalam kondisi ini hanya dilakukan pada sedikit ruangan didasarkan pada asumsi bahwa ruangan yang tidak memiliki jendela dan berdinding masif akan memiliki tingkat kebisingan yang setara. Sementara ruangan yang memiliki jendela ke arah jalan raya memang terdiri dari dua ruangan saja, yaitu: R.510 dan R512. Sehingga kedua ruangan tersebut dianggap sebagai perwakilan untuk mengetahui efek dari kebisingan lalu lintas ke dalam ruangan kelas.

Sementara, kondisi "kosong dengan AC" adalah saat kondisi ruangan kosong, pintu tertutup penuh, namun sistem AC dijalankan pada kondisi operasional. Pengukuran dengan kondisi "kosong dengan AC" dilakukan pada 13 dari 15 ruangan sebagaimana disebutkan pada Tabel 1. Ruangan yang dikecualikan adalah ruangan dengan kode DOSEN dan R.524. Pengukuran dengan kondisi ini dilakukan pada banyak ruangan karena pengaruh AC sebagai sumber bising dapat saja berbeda akibat perbedaan tinggi alat pendingin dalam ruangan, merek dan jenis alat yang digunakan, serta kondisi perawatan peralatan. Namun demikian, penelitian ini tidak melihat perbedaan dalam peralatan AC yang ada di dalam ruangan, tetapi lebih ke arah perbedaan tingkat kebisingan yang dihasilkan dari pengoperasian alat.

Pengambilan sampel yang dilakukan pada setiap ruangan dilakukan dengan mengikuti arahan berikut:

a) Memastikan bahwa ruangan dalam keadaan kosong, serta pintu dapat ditutup dengan rapat; 
b) Untuk pengukuran dalam kondisi "kosong tanpa AC" maka perangkat AC harus dalam kondisi tidak beroperasi;

c) Untuk pengukuran dalam kondisi "kosong dengan AC" maka perangkat AC harus sudah dinyalakan setidaknya 5 menit sebelum pengukuran dilakukan dan selalu dalam kondisi beroperasi selama pengukuran dilakukan;

d) Pengukuran dilakukan dengan menegakkan alat SLM yang dilengkapi dengan gabus filter pada mikrofon di tengah-tengah ruangan. Alat SLM harus diletakkan di atas meja atau kursi;

e) Pengukuran tingkat kebisingan selama rentang waktu 1 hingga 5 menit dengan periode pengukuran per 1 detik. Semisal, rentang waktu pengukuran untuk ruangan "kosong tanpa AC" dianggap cukup selama 1 menit karena variasi kebisingan yang rendah;

f) Setelah pengukuran tingkat kebisingan selesai dilakukan, maka seluruh data diunggah ke perangkat komputer.

\subsection{Pengolahan Data}

Pengolahan data setelah hasil rekaman diunduh dari alat SLM mengikuti langkah-langkah berikut ini:

a) Mengonversi format data hasil unduhan ke format file .xls agar dapat diolah dengan menggunakan piranti lunak Microsoft Excel.

b) Mengonversi nilai tingkat dari hasil pengukuran SLM dalam satuan dBA ke nilai tingkat intensitas kebisingan dengan menggunakan persamaan [19]:

$$
I=10^{\left(\frac{d B A}{10}\right)}
$$

dengan $\mathrm{I} \quad=$ intensitas kebisingan

$\mathrm{dBA}=$ tingkat kebisingan hasil pengukuran SLM

c) Menghitung besaran intensitas kebisingan rata-rata yang dihitung dengan menggunakan persamaan:

$$
\text { Intensitas rata }- \text { rata }=\left(\sum_{i}^{n} I_{i}\right) / n
$$

dengan I = intensitas kebisingan

$\mathrm{n} \quad=$ jumlah data

d) Menghitung tingkat kebisingan ekuivalen $\left(\mathrm{L}_{\mathrm{eq}}\right)$ dengan menggunakan persamaan:

$$
L_{e q}=10 \times \log (\text { Intensitas rata }- \text { rata })
$$

dengan $\mathrm{L}_{\mathrm{eq}} \quad=$ tingkat kebisingan ekuivalen $(\mathrm{dBA})$

\section{Hasil dan Pembahasan}

Hasil pengukuran yang dilakukan kemudian dianalisis untuk mengetahui tingkat kebisingan ekuivalen $\left(\mathrm{L}_{\mathrm{eq}}\right)$ pada setiap titik sampling. Hasil perhitungan disajikan pada Tabel 2.

Tabel 2. Tingkat kebisingan ekuivalen di lokasi pengambilan sampel kebisingan

\begin{tabular}{clcc}
\hline \multirow{2}{*}{ Kode } & \multicolumn{1}{c}{ Jenis Ruangan } & \multicolumn{2}{c}{ Tingkat Kebisingan (Leq) dalam dBA } \\
& \multicolumn{1}{c}{ Kosong Tanpa AC } & 41,10 \\
ACC & Ruang Laboratorium Akuntansi & 32,19 & 48,68 \\
AUD & Ruang Auditorium & 33,24 & 46,13 \\
DOSEN & Ruangan Kerja Dosen & 35,94 & 37,97 \\
R.510 & Studio Gambar Kecil & & 39,19 \\
R.511 & Ruang Kuliah dan Theater & 35,04 & 40,84 \\
R.512 & Ruang Laboratorium Fisika & & 39,46 \\
R.513 & Ruang Kelas & & 38,98 \\
R.514 & Ruang Kelas & 33,00 & 38,64 \\
R.515 & Ruang Kelas & & 41,93 \\
R.518 & Ruang Simulasi Sidang & & 39,55 \\
R.520 & Ruang Kelas & & 43,43 \\
R.521 & Ruang Kelas & & 42,65 \\
R.522 & Ruang Kelas & 32,14 & \\
R.523 & Studio Gambar Besar & & \\
R.524 & Studio Komersial & & \\
\hline
\end{tabular}

Sumber: Hasil analisis (2018) 
Hasil perhitungan tingkat kebisingan yang disajikan pada Tabel 2 menunjukkan beberapa hal yang menarik untuk dipelajari, di antaranya:

a) Tingkat kebisingan ruang dalam keadaan "kosong tanpa AC" bervariasi antara 32,14 hingga 35,94 dBA. Namun, di antara mereka terdapat dua kelompok, yaitu ruangan dengan jendela (R.510 dan R.512) serta ruangan empat lainnya tanpa jendela. Tampak bahwa kelompok ruangan dengan jendela memiliki tingkat kebisingan antara 35,04-35,94 dBA, sedangkan kelompok ruangan tanpa jendela memiliki tingkat kebisingan antara 32,14-33,24 dBA. Hasil ini kemudian dianalisis lebih lanjut dengan menggunakan ANOVA satu faktor, sebagaimana disajikan pada Tabel 3. ANOVA dilakukan dengan menggunakan seluruh data intensitas kebisingan pada setiap lokasi sampling yang dianalisis.

Tabel 3. Hasil ANOVA untuk ruangan kosong tanpa AC

\begin{tabular}{lllll}
\hline Lokasi Basis & Leq (dBA) & Lokasi Pembanding & Leq (dBA) & Probabilitas \\
\hline AUD (Auditorium) & 32,19 & R.510 (Studio Gambar Kecil) & 35,94 & $* 0,0027$ \\
& & R.512 (Ruang Lab Fisika) & 35,04 & $* 6,07 \times 10^{-5}$ \\
& & R.518 (Ruang Simulasi Sidang) & 33,00 & 0,3921 \\
& & R.524 (Studio Komersial) & 32,14 & 0.9585 \\
& & DOSEN (Ruang Dosen) & 33,24 & 0,4468 \\
\hline R.510 (Studio Gambar Kecil) & 35,94 & R.512 (Ruang Lab Fisika) & 35,04 & 0,1414 \\
\hline
\end{tabular}

Sumber: hasil analisis; Catatan: * signifikan pada $\alpha=5 \%$

Hasil pada tabel 3 menunjukkan suatu fenomena yang menarik, bahwa pada tingkat kepercayaan 95\% $(\alpha=5 \%)$, tingkat kebisingan "kosong tanpa AC" di ruang Auditorium adalah sama dengan ruangan R.518, R.524, dan DOSEN. Keempat ruangan tersebut tidak memiliki jendela dan berdinding masif. Sedangkan, tingkat kebisingan di R.510 dan R.512, yang memiliki jendela menghadap ke jalan raya, menunjukkan perbedaan yang signifikan dengan ruang Auditorium.

b) Tingkat kebisingan pada ruangan AUD, R.510, R.512, dan R.518 dilakukan dengan kondisi "kosong tanpa AC" dan "kosong dengan AC". Hal ini menarik untuk dikaji lebih lanjut karena dapat memberikan petunjuk apakah penggunaan $\mathrm{AC}$ di ruangan dapat memberikan peningkatan tingkat kebisingan yang signifikan. Hasil analisis menggunakan ANOVA dari data intensitas kebisingan di setiap ruangan yang diuji disajikan pada Tabel 4.

Tabel 4. Hasil ANOVA untuk ruangan kosong tanpa dan dengan AC

\begin{tabular}{lccc}
\hline \multicolumn{1}{c}{ Lokasi } & $\mathrm{L}_{\mathrm{eq}}$ Tanpa AC $(\mathrm{dBA})$ & $\mathrm{L}_{\mathrm{eq}}$ dengan $\mathrm{AC}(\mathrm{dBA})$ & Nilai Probabilitas \\
\hline AUD (Auditorium) & 32,19 & 48,68 & $* 1,07 \times 10^{-69}$ \\
R.510 (Studio Gambar Kecil) & 35,94 & 46,13 & $* 3,90 \times 10^{-46}$ \\
R.512 (Ruang Lab Fisika) & 35,04 & 39,19 & $* 1,20 \times 10^{-33}$ \\
R.518 (Ruang Simulasi Sidang) & 33,00 & 38,64 & $* 3,79 \times 10^{-34}$ \\
\hline
\end{tabular}

Sumber: hasil analisis; Catatan: * signifikan pada $\alpha=5 \%$

Hasil pada Tabel 4 menunjukkan bahwa penggunaan AC akan memberikan perbedaan tingkat kebisingan yang signifikan pada tingkat kepercayaan 95\%. Namun demikian peningkatan tingkat kebisingan sangat bervariasi dari 4,15 dBA di R.512 hingga 16,49 dBA di AUD.

c) Tingkat kebisingan pada tiga belas ruangan yang diukur pada kondisi "kosong dengan AC" adalah pada rentang 37,97 - 48,68 dBA. Variasi kebisingan ini sangat lebar dan setiap ruangan memiliki nilai yang berbeda. Apabila nilai kebisingan pada ruangan "kosong tanpa AC" diukur menggunakan hasil di ruang AUD setinggi 32,19 dBA, maka penggunaan AC dapat meningkatkan kebisingan antara 5,78-16,49 dBA.

\section{Kesimpulan}

Hasil perhitungan tingkat kebisingan pada Tabel 2 khususnya pada ruangan yang tidak memiliki jendela dan berdinding masif, serta dalam keadaan kosong tanpa AC menunjukkan kisaran yang berada di bawah 35 dBA. Bila angka ini dibandingkan dengan standar ANSI S12.60-2002, maka kondisi ruangan yang tepat untuk tempat belajar dapat dicapai. Namun ada beberapa kekurangan dalam menciptakan ruangan belajar yang nyaman, yaitu: ketiadaan jendela yang memungkinkan siswa melihat dunia luar pada saat belajar; serta sirkulasi udara yang tidak berjalan karena sistem AC yang tidak beroperasi.

Bila ruangan kelas akan dibuat lebih nyaman dengan menambahkan jendela kaca, maka ada kemungkinan terjadi peningkatan kebisingan akibat aktivitas di luar kampus. Lalu lintas sebagai contoh dapat memberikan peningkatan kebisingan sekitar $3 \mathrm{dBA}$, walaupun ruangan R.510 dan R.512 berada 
pada lantai 5 dan berjarak sekitar lebih dari 100 meter dari jalan raya serta dilindungi oleh jendela dengan kaca yang tebal dan tidak dapat dibuka. Tingkat kebisingan di dalam ruangan kelas tentunya akan meningkat apabila lokasi kelas lebih dekat ke jalan raya, serta memiliki jendela dengan kaca tipis dan dapat dibuka. Adalah suatu hal yang ideal, apabila ruangan kelas berada cukup jauh dari jalan raya guna menurunkan tingkat kebisingan. Namun, di perkotaan yang memiliki keterbatasan lahan, ruangan kelas terkadang berada berbatasan langsung dengan jalan raya. Pembatasan kecepatan kendaraan, pelarangan membunyikan klakson, dan pelarangan penggunaan knalpot bersuara keras sangatlah sulit dilakukan di Indonesia. Oleh karena itu, desain ruangan kelas harus memasukkan beberapa kriteria, di antaranya: memiliki dinding masif pada sisi yang menghadap jalan raya atau sumber bising lain; jendela ruangan dibuat dari bahan kaca yang cukup tebal dengan bingkai yang kuat serta dapat ditutup dengan rapat dan kedap; pintu kelas juga harus terbuat dari material yang tahan lama serta dapat ditutup dengan rapat dan kedap.

Ruangan kelas di beberapa kota besar di Indonesia memerlukan sistem AC guna menurunkan temperatur ruangan serta mengurangi debu atau bau dari polusi udara. Solusi ini nampaknya menjadi suatu jawaban yang lebih nyata di masa mendatang akibat perubahan iklim global serta peningkatan polusi udara. Terlepas dari konsekuensi peningkatan biaya yang harus dikeluarkan, pengoperasian peralatan AC di kelas terbukti dapat meningkatkan tingkat kebisingan dalam kelas. Penelitian ini menunjukkan bahwa pengoperasian AC akan menambah tingkat kebisingan antara 5,78-16,49 dBA. Pengamatan di lapangan saat pengambilan sampel dilakukan menggambarkan bahwa AC yang dipasang memiliki kipas yang berada di dalam ruangan. Sistem AC tersebut adalah produk yang umum di pasaran. Beberapa AC juga didapati menimbulkan suara yang lebih berisik akibat perputaran kipas yang tidak lancar. Oleh karena itu, desain AC untuk ruangan kelas sepatutnya menggunakan sistem yang dikhususkan untuk ruangan belajar. Sistem baru memungkinkan sirkulasi udara yang lebih optimal untuk mengurangi penggunaan listrik, sistem venting yang lebih senyap, serta sistem penyaringan udara yang lebih baik.

\section{Pernyataan}

Penulisan artikel ini merupakan salah satu luaran penelitian yang didanai oleh Lembaga Penelitian dari salah satu universitas swasta di Jakarta Barat.

\section{Referensi}

[1] A. Bell, "Noise: An occupational hazard and public nuisance," World Health Organization, Geneva, 1996.

[2] S. F. Rostiyanti, I. M. I. M. Brunner and A. I. Safitri, "Minimalisasi kebisingan melalui penggunaan ruang kelas kedap suara guna menjaga kinerja siswa," Urban Environmental Engineering and Technology, vol. 2, no. 1, pp. 44-50, 2018.

[3] M. Concha-Barrientos, D. Campbell-Lendrum and K. Steenland, "Occupational noise: Assessing the burden of disease from work-related hearing," World Health Organization, Geneva, 2004.

[4] B. M. Shield and J. E. Dockrell, "The effect of noise on children at school: A review," Journal of Building Acoustics, vol. 10, no. 2, pp. 97-106, 2003.

[5] Bulunuz, N., Bulunuz, M., Orbak, A.Y., Mulu, N., \& Tavşanli, Ö.F., "An evaluation of primary school students' views about noise levels in school," International Electronic Journal of Elementary Education, vol. 9, no. 4, pp. 725-740, 2017.

[6] M. Hodgson, "UBC-Classroom Acoustical Survey," Canadian Acoustics, vol. 22, no. 4, pp. 3-10, 1994.

[7] American Speech-Language-Hearing Association, "American National Standard on Classroom Acoustics," [Online]. Available: https://asha.org. [Accessed 293 2018].

[8] K. Mealings, "Classroom acoustic conditions: Understanding what is suitable through a review of national and international standards, recommendations, and live classroom measurements," in Proceedings of Acoustics 2016, Brisbane, 2016.

[9] Keputusan Menteri Negara Lingkungan Hidup Nomor: Kep-48/MENLH/11/1996 tentang Baku Mutu Tingkat Kebisingan, 1996.

[10] B. Shield, R. Conetta, J. Dockrell , D. Connolly, T. Cox and C. Mydlarz, "A survey of acoustic conditions and noise levels in secondary school classrooms in England," Journal of Acoustical 
Society of America, vol. 137, no. 1, pp. 177-188, 2015.

[11] H. A. Knecht, P. B. Nelson, G. M. Whitelaw and L. L. Feth, "Background noise levels and reverberation times in unoccupied classrooms: predictions and measurements," American Journal of Audiology, vol. 11, pp. 65-71, 2002.

[12] M. Asselineau, Building Acoustics, Boca Raton, FL: CRC Press, 2015.

[13] L. C. Brill, "Exploring the correlation between occupied and unoccupied noise levels in K-12 classrooms," University of Nebraska, Lincoln, 2017.

[14] K. M. Chan, C. M. Li, E. P. Ma and E. M. Yiu, "Noise levels in an urban Asian school environment," Noise Health, vol. 17, no. 74, pp. 48-55, 2015.

[15] J. S. Bradley and H. Sato, "The intelligibility of speech in elementary school classrooms," Journal of Acoustical Society of America, vol. 123, no. 4, p. 2078-2086, 2008.

[16] Handoko, J. P. S., "Pengendalian kebisingan pada fasilitas pendidikan studi kasus gedung sekolah pascasarjana UGM Yogyakarta," Jurnal Sains dan Teknologi Lingkungan, vol. 2, no. 1, pp. 32-42, 2010.

[17] Putra, F. \& Lisya, S. Y., "Tingkat kebisingan lalu lintas kendaraan di gedung 1 Sekolah Tinggi Teknologi Industri (STTInd) Padang," Jurnal Sains dan Teknologi, vol. 17, no. 1, pp. 1-7, 2017.

[18] Y. M. Leatemia, T. A. Adhisantoso and A. Makmur, "Studi analisis kontribusi kegiatan di Kompleks Terpadu Ukrida-Penabur terhadap kapasitas ruas jalan Tanjung Duren Raya dan jalan Letjen S. Parman," Jurnal Teknik dan Ilmu Komputer, vol. 5, no. 19, pp. 257-268, 2016.

[19] M. L. Davis and D. A. Cornwell, Introduction to Environmental Engineering, 2nd Ed, Singapore: McGraw Hill, 1991. 